\title{
Sir Creek and its Legal and Political Significance and Resolution
}

\author{
Sikander Ahmed Shah
}

\begin{abstract}
The Sir Creek dispute remains a serious hurdle in the way of any meaningful progress on ties between Pakistan and India, but it also has huge potential to be resolved by recourse to international law and bilateral negotiations. In this respect, I will explore certain important historical, legal and political aspects of the Sir Creek dispute in order to better inform future dialogue between the two states. Among other things, I will discuss the status of the law and its application to the dispute. With regards to Sir Creek, other considerations that will be examined include: the impetus for both states to adhere to the law of the sea, the potential of international dispute resolution and the appropriate choice of procedure for settlement, the relevant weightage to be given to historical and special circumstances as well as the significance to relevant international legal proceedings on the dispute. The various factors relevant to the amicable settlement of such river boundary disputes will also be holistically examined.
\end{abstract}




\section{Introduction}

Border disputes between Pakistan and India have existed since the birth of these two neighbours. The most contentious of all of these is, undoubtedly, that of the Kashmir region. The Kashmir dispute has become a full-fledged conflict, rife with military involvement and the deaths of thousands of innocents. Alternatively, the Sir Creek border dispute is relatively straightforward and resolvable. Historically, the Sir Creek area was of little significance to Pakistan and India. However, the issue recently gained prominence due to the need to establish maritime boundaries and the discovery of potential resources there. The establishment of India and Pakistan's maritime boundaries along the Arabian Sea are contingent upon the resolution of India and Pakistan's disputed land borders: the Sir Creek border between them. Whosoever holds the Sir Creek will also gain rights to an enlarged maritime zone. Moreover, India seeks, at minimum, partial ownership of the Sir Creek; Pakistan hopes to retain complete rights to the Sir Creek. This will impact their Exclusive Economic Zones and Continental Shelves. Therefore, it is in the interest of both Pakistan and India to decide the boundaries of the Sir Creek.

The Sir Creek disagreement is essentially over whether the border between Sindh and Gujarat is within the estuary or on the eastern bank of the estuary. If the border is within the estuary itself, then both India and Pakistan will have ownership of the waters of the Sir Creek. If the border is determined to be the eastern bank of the Sir Creek estuary, then Pakistan has full ownership of the creek and India does not have access to the waters. The two nations will also have to assess the extent of change in the geography of the estuary. If an estuary is naturally changing and shifting through a process called accretion, the default position is that this occurrence affects the boundary delimitation. All of these considerations must be made before this issue can be put to rest. In order to thoroughly understand this dispute, it is necessary to analyse the historical context of the area and discuss the applicability of international law principles. The legal principles in question are the concept of utipossidetisjurisand the thalweg and medium filusaquaedoctrines for delimitation of river boundaries. These will be discussed in detail. 
It remains to be determined whether the Sir Creek dispute can be resolved bilaterally, or whether a third-party arbiter will be sought. Pakistan's preference is that the issue be resolved with a third-party. However, India resolutely declined this and insisted that all issues with Pakistan be resolved bilaterally under the Shimla Agreement. It is imperative that India and Pakistan overcome this mere political impasse. Not only do maritime boundaries and resource extraction depends upon this, but the lives of innocent fishermen also hang in the balance until this dispute can be put to rest.

It is also important that Pakistan and India should allow technical and hydrographic teams to complete their survey of the general area. In order to progress in these talks, accurate and mutually agreed upon maps and graphs are essential. Once these teams are allowed to collect their data and map their work, only then can India and Pakistan have substantive talks. There is also the matter of fishermen arrests in the Sir Creek area. The routine arrests of these fishermen create tension in between Pakistan and India. Furthermore, these are potential violations of international human rights and of international law, which should be addressed.

In order for this issue to move forward, it may be pertinent to explore all options when deciding how to resolve the Sir Creek dispute. Pakistan favors third-party involvement and India prefer bilateral resolution. As a means of confidence building, Pakistan should consider resolving this dispute bilaterally. Although arbitration is the preference for Pakistan, there is no guarantee that the inclusion of a third-party arbiter will complete work in Pakistan's favor. An award by an arbitral tribunal can be adverse to Pakistan's stated position in certain respects. The Sir Creek issue is not one that can be resolved strictly legally. This issue has morphed significantly over time, and a political resolution may be optimal. This way, Pakistan can link the Sir Creek resolution to other border disputes, such as Siachen, and seek an amicable resolution to both. Using the Sir Creek negotiations as a bargaining chip could further aid Pakistan's case in resolving Siachen- something that may not be possible in an arbitral tribunal. If political, bilateral resolution is not an option, then Pakistan should include a third-party arbiter. It may be best that Pakistan explores all options when determining the method of resolution- bilateral or arbitration. Furthermore, the resolution of this border dispute in goodwill will also ensure the continual goodwill during the establishment of maritime boundaries and discovery of respective 
Exclusive Economic Zones. India and Pakistan will be working in close proximity in their territorial seas; it is best, therefore, that relations are amiable and not hostile.

\section{Geographical Description of the Sir Creek}

The Sir Creek is located along the southeastern border of the Sindh province of Pakistan and the western border of the Gujarat province in India. ${ }^{1}$ This area is called the Greater Rann of Kutch, a marshland situated along the Arabian Sea. There is another creek of importance in the Rann of Kutch area: the Kori Creek is east of the Sir Creek and belongs entirely to the Gujarat province, which was historically the Kutch Darbar. During colonial rule, Sindh was part of the Bombay Presidency, and the Rann of Kutch Darbar ruled the adjacent area in Gujarat. These were the two authorities in this region during British rule, before independence. In a compromise titled Resolution 1192, or the 1914 Resolution, these governments decided the rights over two creeks: the Sir Creek and the Kori Creek. The Government of Bombay agreed to relinquish its claim over the Kori Creek in order to gain full rights to the Sir Creek. This compromise, Resolution 1192, will be discussed in thorough detail in the following section.

The Sir Creek is a 96-kilometer long estuary that stretches up from the Arabian Sea, where the mouth of the river opens up. The area is believed to be rich in various resources, including minerals, petroleum, gas, oil, and plant life. These resources can be extracted and provide a source of commercial exploitation. The Sir Creek estuary is considered to be non-navigable, which means it largely cannot be traversed for commercial use. Legally, in order for a river to be considered navigable, it must "in its ordinary and natural condition afford a channel for useful commerce," 2 , that "the tide in the river ebbs and flows" 3 and "a small stream intermittently navigated is not necessarily navigable." ${ }^{4}$ Under these requirements, the Sir Creek can be classified as non-navigable. India claims that the Sir Creek is navigable during high tide. However,

1 A.G Noorani, "Easing The Indo-Pakistan Dialogue On Kashmir: Confidence-Building Measures For The Siachen Glacier, Sir Creek And The Wullar Barrage Disputes", Henry L. Stimpson Center, Washington D.C, (April 1994), (Occasional Paper 16)

2 Hanes v. Oklahoma, (Okla. Crim. App. 1998)

3 Wisdom, A.S. (1975), The Law Of Rivers And Watercourses, Shaw \& Sons London

4 Ibid.pp. 58 
that is insufficient for classification as a navigable river overall. The classification of the Sir Creek as navigable or non-navigable is important to India's claim over the estuary, which will be elaborated upon in the discussion of the Indian stance.

Because the bodies of water change over time, it is essential to determine the extent of accretion and avulsion on the estuary boundary. Accretion is the slow and natural movement of the river. The extent of accretion impacts river boundaries. If a river is naturally moving eastward or westward then, accordingly, the boundary may also shift. However, if a treaty specifies that movement of a river will have no effect on the boundary, then accretion has no impact on the border. In the case of the Sir Creek, reports indicate that there has been some accretion eastward into Indian territory. This can result in lost territory of India under the default rule, because the boundary would change in accordance with international law. The process of avulsion, a more sudden form of accretion, has no effect on river boundaries, unless agreed otherwise.

\section{History of the Sir Creek Dispute}

a. Resolution 1192: The Sir Creek border was not a contentious matter for many decades. Predating the Partition of India and Pakistan, the matter had been settled between the Government of Bombay and the Kutch Darbar. The two presiding governments reached a compromise in 1914 that clearly delimited the borders between the two provinces. This compromise, titled Resolution 1192, was promulgated on February 24, 1914. The resolution refers to a 1913 letter, titled Letter No. 5543, from the Government of Bombay to the Government of India, Foreign Department. This letter provides the opinions used in forming the resolution- that the boundary should be the green line, and not the thalweg of the river. Resolution 1192 was a compromise that gave the entirety of the Kori Creek to the Kutch Darbar and the entirety of the Sir Creek to the Government of Bombay. A map alongside this resolution, referred to as map B-44 or the 1914 Resolution Map, shows a green line along 
the eastern bank of the Sir Creek (see Figure 1) ${ }^{5}$. This green line is referred to as the boundary between Sindh and Kutch.

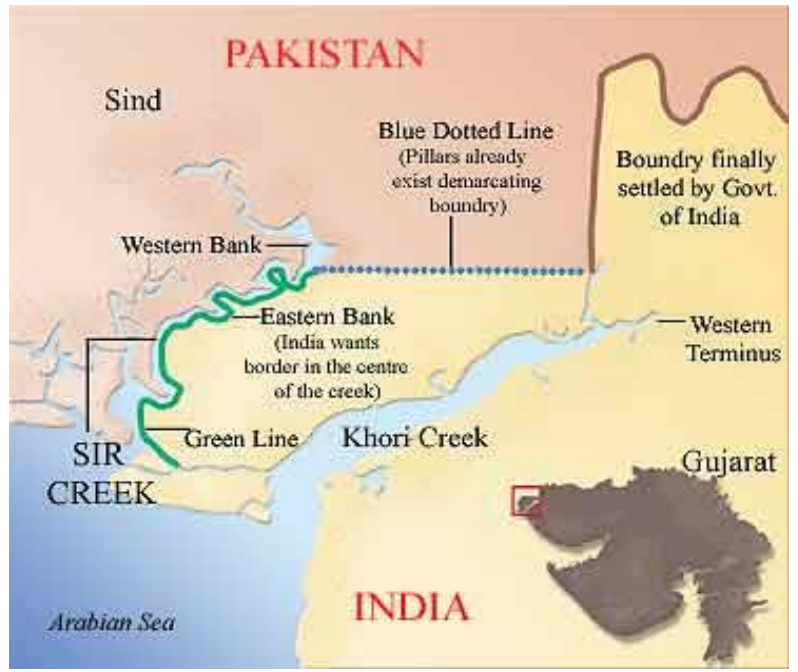

Figure-1 India Pakistan boundary dispute in Gujrat Region

There are two important paragraphs, paragraphs nine and ten, regarding the Sir Creek in Letter No. 5543. Paragraphs nine and ten provide the crux of the arguments of Pakistan and India, respectively. Paragraph nine of the letter states:

"For a full review of the evidence, therefore, Government arrived at the conclusion that the boundary between Cutch and Sindh should be the green line in the accompanying map from the mouth of the Sir Creek to the top of the Sir Creek ... and His Highness the Rao has now expressed his willingness to agree to this compromise. 6

The accompanying map mentioned in the letter is the 1914 Resolution Map, which shows a green line along the eastern bank of the river, not on the river itself. This is evidence that the border is along the bank of the river and not within the river. Since the

5 “Main Question Regarding dispute in Sir Creek Region," India Pakistan boundary dispute in Gujrat Region, October 10, 2013, http://indiapakistanboundarydispute.blogspot.com

6 The Indian Society of International Law, The Kutch-Sind Border Question 17 (1965). Indo-Pakistan Western Boundary, R. Int'l Arb. Awards at 336 
governments of Sindh and the Kutch Darbar, predecessor states of Pakistan and India, agreed upon this boundary, this should be the determined border between India and Pakistan. The Indian position is that the green line was merely symbolic of the fact that the river itself is the border, and therefore, India claims rights to part of the river. India points to paragraph ten of Letter 5543, which states:

On this proposed settlement being referred to the Commissioner in Sindh that officer agreed to the adoption, as the frontier line, of the blue dotted line running due east from the top of the Sir Creek. He observed, however, that the Sir Creek changes its course from time to time and the western boundary of the area, which it is proposed to surrender to the Rao, should, therefore, be described as "the centre of the navigable channel of the Sir Creek". A similar method has been adopted in determining the boundary between the Khairpur State and British territory where the river Indus is the boundary, and the position of the navigable channel varies from year to year... I am to explain that the term "navigable" is really inappropriate in the larger sense. The creek is, of course, tidal, and it is only on certain conditions of the tide that the channel is navigable and then only to country craft as far as the point from which the proposed boundary turns due east from the Creek. ${ }^{7}$

India claims that this quote from the Commissioner of Sindh proves that the boundary should be the center of the navigable channel of the Sir Creek. They go further to maintain that the green line on the accompanying the map is merely symbolic, and the creators of the map meant for the green line to represent the center of the navigable river at the border. However, the writer of the letter, from the Government of Bombay, mentions that the creek is, contrary to the quote, largely non-navigable. It is clear from his disagreement that the green line was not intended to be merely "symbolic", since the author of Letter 5543, the Secretary to the Government of Bombay, disagrees with the concept of the center of the river as a border. The Indian stance also claims that the border outlined in Resolution 1192 was implemented by the construction of pillars in 1924. Pillars were constructed all along the rest of the border in the 1914 Resolution Map, but no pillars were constructed in the Sir

${ }^{7}$ The Indian Society of International Law, pg 337 
Creek. This may be because the eastern riverbank is the intended border, therefore negating the need for pillars at all. India argues that the absence of pillars implies that the boundary was meant to be fluid, not permanently fixed. Therefore, India claims, the border was understood to be within the river.

No discussion of the Sir Creek can be had without referring to the Resolution 1192 or 1914. This resolution provides the backbone of both the Indian and Pakistani stance. It is important to note that the Indian stance gives little significance to the 1914 Resolution Map. However, this is largely irrelevant because Resolution 1192 itself states that the green line was the explicit boundary between the states of Kutch and Sindh. Whether or not Pakistan accepts the map as only an annexure has no bearing on the reality that Letter 5543 explicitly states the green line as the border.

In order to determine the borders of today, it is vital to define the boundaries of the predecessor states of Kutch and Sindh. The borders of those predecessor states defined the borders of the newly independent countries in 1947, according to the international law doctrine of utipossidetisjuris. This doctrine establishes that newly independent states will inherit the borders of their predecessor states. For example, the province of Sindh in Pakistan inherits the border of the state of Sindh under British India. The province of Gujarat in India inherits the borders of the Rann of Kutch under British India. Therefore, it is essential that the border between Kutch and Sindh be well established. If the pre-partition border can be agreed upon by all parties, then this will inform the delimitation of the Sindh and Gujarat border today (not accounting for the impact of accretion).

\section{b. 1965 Indo-Pakistani Western Boundary Case Tribunal:}

Reaching the point of resolution seems a distant struggle because there is no agreement over a method of resolution. Pakistan wishes to include a third-party arbiter and India refuses to resolve any issues except bilaterally, under the Shimla Agreement. Both India and Pakistan have ratified the United Nations 1982 Convention on the Law of the Sea (UNCLOS), but have not utilized the UNCLOS dispute resolution mechanism, aimed at resolving maritime boundary disputes. 
The major reason behind the Indian reluctance to use a third-party in dispute resolution can be linked back to the Indo-Pakistani Western Boundary Case Tribunal in 1965. This was a case of arbitration that gave Pakistan 10\% of the Rann of Kutch and India $90 \%$. However, after the tribunal, the Indian government suffered from criticism for accepting the tribunal's award of only $90 \%$ of the Rannof Kutch. Arguably, in order to avoid a repeat of this event, and to ensure results based on its own interests, the Indian government refuses to enter into third-party arbitration with Pakistan over any of its border disputes. Instead, they insist all talks be held bilaterally under the Shimla Agreement of 1972. This has proven to be a major roadblock in the resolution of the Sir Creek issue.

c. 2007 Hydrographic Surveys and 2008 Mumbai Attacks: In 2007, both Indian and Pakistani authorities carried out individual hydrographic surveys of the Sir Creek area. This demonstrated a willingness to work together and a major point of progress for the dispute resolution. Both parties agreed upon and exchanged signed maps of the area by March 2007. India and Pakistan seemed close to resolution on this issue. Unfortunately, on November 26, 2008, ten militants orchestrated an attack on various buildings and centers in Mumbai. Killing 179 people, this attack was one of the most fatal in recent Indian history. India claimed that the terrorists were Pakistanis who had entered India by sea. Needless to say, relations between the two disintegrated. The Sir Creek talks were abandoned for a time and little progress was made for years to come.

\section{Pakistani and Indian Stances}

A thorough understanding of the legal principles involved in the Sir Creek dispute is essential to any discussion of the issue. Both India and Pakistan refer to various legal principles when defending their positions regarding rights to the Sir Creek. Historical context has already been provided, detailing the various exchanges over this issue in the past century- ranging from the Resolution 1192 to the 2007 Hydrographic surveys.

The two major principles referred to in these stances are utipossidetisjuris and the thalweg principle of international law. Both India and Pakistan rely on the doctrine of international law, utipossidetisjuris. According to this doctrine, newly independent states 
will inherit the borders of the states before them. For precisely this reason, Pakistan states that the entirety of the Sir Creek belonged to the Government of Sindh before independence. Therefore, the entirety of the Sir Creek belongs to the Pakistani province of Sindh today. India, conversely, claims that the Sir Creek, with the thalweg as the boundary, belonged to the Rann of Kutch. This would mean that the Province of Gujarat, which succeeded the Kutch Darbar, would have the same ownership.

The thalweg principle is, simply put, a way to divide a river and give both states access to the main channel of the river. Division along the thalweg allows civilians from both sides to use the main channel of the river for travel, trade or commerce. The thalweg principle does not necessarily divide the river equally. This is because the thalweg depends on the location of the main channel, which may not be in the middle of the river. It is meant to allow both states access to a navigable portion of the river for trade. Furthermore, the thalweg principle is a fluid boundary. Unlike a permanent land boundary or the median line rule, the thalweg is understood to be a general area, and not a distinct boundary line.

Failing navigability, a river can be divided according to the medium filusaquae rule, which is simply the middle of the river. In the case of the Sir Creek, it is not navigable except occasionally at high tide. Legally, the Sir Creek would be classified as non-navigable. Therefore, if the Sir Creek were shared, the thalweg principle would not apply and the river would be divided along the median line. The median line principle for dividing a river ensures that both states have equal shares of the water.

Importantly, rivers tend to shift as a result of accretion and avulsion. When the river shifts as a result of accretion, the boundary also shifts. This is to ensure access to the main navigable channel of the river for both countries. Accretion, as discussed earlier, is the slow progress of the river. It can shift the river eastward or westward. In the case of the Sir Creek, some geographical changes have been taking place. Reportedly, the mouth of the river has widened, and the river has shifted eastward into Indian territory. If the India-Pakistan border were determined to be along the thalweg, then this would result in the loss of Indian territory. Avulsion, on the contrary, is a more sudden change that does not legally shift the thalweg. For example, if a flood occurs and causes the river to change or shift, the boundary will not be affected. 
States can preempt this in a treaty or agreement and decide if avulsion and accretion should have an effect on the boundary.

Regardless of the principles of the thalweg or median line, any treaty or agreement of borders between states trumps the international law defaults. Use of thalweg as the border is a default principle, if no other agreement on a border exists. If a preexisting treaty was established, such as Resolution 1192, then the boundary should not be defined along the thalweg or median line.

Because Resolution 1192 explicitly mentions an agreement over the Sindh-Kutch border, Pakistan can legally argue that a preexisting treaty existed. Not only did the resolution rely on a letter, which explicitly denies the thalweg as a border, but it also refers to demarcation on a map. The 1914 Resolution Map was prepared by the Surveyor General of India and included a distinct green line defining the border. This document clearly indicated a preexisting agreement between the predecessor states of Kutch and Sindh. Therefore, no international law doctrine, such as the thalweg or medium filusaquae principles, can apply to the Sir Creek.

India's argument rests heavily upon the 1924 implementation of Resolution 1192 of 1914: the demarcation of the border with pillars. There is evidence, they claim, that the region was divided along the thalweg of the river, and not along the bank. Pillars were erected all along the border but not along the bank of the river. India claims that this was intentional because the border was expected to be fluid, like the thalweg. They state that if the boundary were intended to be fixed, then there would have been pillars to indicate this permanent border.

\section{Consequences of Resolution}

India and Pakistan have halted negotiations on a multitude of issues since the 2008 Mumbai Attacks. As a result, both nations have suffered from a lack of trade and a lack of security. There is a whole host of issues that neither India nor Pakistan can resolve without cooperation. Although the Sir Creek is considered a resolvable dispute, it is inextricably linked to the EEZ and the Continental Shelf. As a relatively straightforward matter, the Sir Creek dispute has immense potential to serve as a confidence building measure for the two governments. If Pakistan and India can amicably resolve this dispute, it will serve as a 
testament that the two can work together. Until the Sir Creek issue is resolved, Pakistan prefers not to discuss maritime boundary delimitation. Maritime boundary delimitation would be hugely beneficial to Pakistan, so the EEZ and Continental Shelf may be adequately explored. Finally, many fishermen in the area are routinely arrested because of their ignorance of the border issue. These three consequences should provide impetus enough for both India and Pakistan to start working towards an amicable resolution.

As a consequence of the Sir Creek dispute, a large number of fishermen have been arrested by both Pakistani and Indian authorities. These fishermen often traverse the river ,believing that they have not crossed any international borders. Because their respective nations are unable to delimit the border along the Sir Creek, they are unaware that they have committed a crime when they travel along the river. As a result of this alleged negligence, they are often arrested by the neighbouring country. Once jailed, these fishermen lose their belongings, are allegedly frequently tortured and denied access to assistance. These conditions if true violate international law. Both sides concede that the issue is a relatively straightforward one. Therefore, the resolution of this issue is a prime starting point for resolutions of various other border issues. Since Pakistan is keen on linking the Sir Creek resolution to the discussion of other India-Pakistan disputes, the Sir Creek issue can serve as an ideal springboard for talks on the other Indo-Pak disputes. A successful resolution of the Sir Creek will pave the way not only for other border resolutions, but also maritime boundary delimitations and establishments of India and Pakistan's EEZs.

A country's Exclusive Economic Zone (EEZ) is the portion of the adjoining sea that the country has certain rights over. Usually, these extend to the discovery of natural resources and tapping of minerals in that area. The Continental Shelf of a nation is the underwater landmass directly linked to the land territory of the nation. In order for Pakistan's EEZ and Continental Shelf to be discovered and exploited, Pakistan must first settle its land disputes with India. Particularly, the Sir Creek dispute. The ownership of the Sir Creek will affect the EEZ and the Continental Shelf of Pakistan. If, for example, the thalweg of the Sir Creek is used as the boundary between India and Pakistan, then Pakistan could lose thousands of square kilometers of the EEZ. These are closely related. India has expressed an interest that Pakistan and India first establish their EEZ and Continental Shelves, starting from the frontier up until the area that would be affected by the Sir Creek, leaving that area 
untouched until the Sir Creek dispute is resolved. However, Pakistan seeks to first address the Sir Creek issue as the two are linked. Pakistan insists that only once the Sir Creek issue is resolved can both nations determine their EEZ and Continental Shelves. Once determined, only then can Pakistan begin to exploit the potential commercial gain of the area.

The area surrounding the Sir Creek, as well as the broader area of the EEZ, is believed to be rich in minerals and petroleum and gas. If Pakistan is able to tap into these resources, there is much to be gained. Any loss of the Sir Creek area to India would also affect Pakistan's territorial sea, thereby lessening its Exclusive Economic Zone for commercial exploitation. Not only does its immediate area contain potential resources, but the adjoining EEZ and Continental Shelf also contain commercially viable resources to be extracted. Therefore, the resolution of the Sir Creek dispute would not only be politically beneficial but also economically gainful.

\section{Policy Recommendations}

A longtime hindrance to the resolution of the Sir Creek issue has been the question of how to resolve the boundary dispute. Pakistan and India have been unable to agree over whether the issue should be resolved bilaterally or by involving a tribunal or a third party. India has insisted on the former method while Pakistan has insisted on the latter.

First and foremost, predicting the outcome of a tribunal is difficult. There is no guarantee that a tribunal award would be agreeable to Pakistan. Instead of tribunals, then, there is the option of arbitration by a third party or bilateral talks. Arbitration and bilateral resolution would ensure that Pakistan does not have to accept an outcome that it does not agree with. Therefore, Pakistan can remain in talks until an amenable resolution is reached.

Furthermore, solving the matter politically, not legally, could benefit Pakistan. Political resolution allows Pakistan more bargaining power. Pakistan can include concessions and agreements from one talk to another. This would not be possible in a legal setting. The option of bilateral talks could potentially offer Pakistan an unexpected advantage. 
If the Sir Creek border issue can be resolved, it paves the way for the resolution of many more issues. Namely, it should lead to the establishment of Pakistan's Exclusive Economic Zone. It is prudent to note that India and Pakistan will likely be exploited nearby maritime areas for commercial use. In the interest of future cooperation between the two countries, it is best to resolve the present the Sir Creek issue amicably- not only as neighbouring nations, but also as neighbouring economies. 